NBER WORKING PAPER SERIES

\title{
PRICING IN INTERNATIONAL MARKETS: LESSONS FROM \\ THE ECONOMIST
}

Atish R. Ghosh
Holger C. Wolf

Working Paper No. 4806

\section{NATIONAL BUREAU OF ECONOMIC RESEARCH 1050 Massachusetts Avenue Cambridge, MA 02138 \\ July 1994}

This paper is part of NBER's research programs in International Finance and Macroeconomics and International Trade and Investment. Any opinions expressed are those of the authors and not those of the National Bureau of Economic Research. 


\title{
PRICING IN INTERNATIONAL \\ MARKETS: LESSONS FROM THE ECONOMIST
}

\begin{abstract}
Export firms are often assumed to stabilize destination market prices in the face of nominal exchange rate changes in order to protect market share. We show that standard tests.of such pricing to market fail to discriminate against the alternative hypothesis of menu costs. As a case study, we examine the characteristics and determinants of changes in the cover prices of The Economist magazine in a sample of twelve countries over the floating rate period. We find that, while the law of one price fails, there is no evidence of systematic attempts to offset nominal exchange rate movements. Instead, the findings are consistent with menu cost driven pricing behavior.
\end{abstract}

Atish R. Ghosh

Woodrow Wilson School

Princeton University

Princeton, NJ 08544
Holger C. Wolf

Stern Business School New York University 44 West 4th Street, MEC 7-78 New York, NY 10012 and NBER 


\section{Introduction}

The slow response of the US trade balance to the dollar depreciation in the mid-1980s has often been blamed on foreign exporters' non-competitive pricing strategies:

This phenomenon results from the choice of foreign producers to boost profit margins as their currencies depreciate against the dollar and to allow these margins to narrow so as to maintain market share as their currencies appreciate against the dollar.....foreign producers widened their profit margins considerably during the 1980-84 appreciation of the dollar. This provided them ample room to narrow profit margins by limiting price increases and thus maintain market share as the dollar depreciated. Indeed, non-oil import prices actually declined in 1985 and began to rise only in 1986.

1987 Economic Report of the President, p.116.

In response to these developments, a substantial and growing literature on pricing in international markets has come into existence, increasingly replacing the classical paradigm of the law of one price (LOOP) by models explicitly incorporating

non-competitive market structures. ${ }^{1}$ In these pricing to market (PTM) models, firms charge different local prices across export markets, reflecting the particular local competitive situation, and typically absorb part of any exchange rate movement by altering the home currency export price, so that there is incomplete pass-through of exchange rate movements to local prices.

An understanding of the pricing behavior of firms operating in multiple international markets is of considerable interest: incomplete passthrough has important implications for the ability of nominal exchange rate changes, (whether under fixed or floating rates), to equilibrate trade imbalances. In this paper, we argue that more research on pricing behavior in international markets is needed. Specifically, we challenge the view that incomplete passthrough and strategic price setting are two sides of the same coin. We show that the combination of menu costs (MC) and invoicing in the foreign currency - a common practice for non-US exporters- will lead to an observationally undistinguishable sluggish response of current prices to current exchange rate movements, particularly if aggregate

\footnotetext{
'See Dornbusch (1987), Froot and Klemperer (1989), Krugman (1987) inter alia.
} 
price indices are examined. Incomplete pass-through may thus reflect postponed, rather than deliberately forestalled, adjustment - with significantly different policy implications. The danger of misinterpreting menu cost driven delays as deliberate strategic price setting is particularly acute in studies focusing on broad price indices which hide the tell-tale pattern of individual price adjustments. Unfortunately, given the scarcity of individual price series on internationally traded goods much of the existing literature [Hooper and Mann (1989), Knetter (1989, 1993), Marston, Feenstra (1989), Feenstra et al. (1993), Harrison (1993), inter alia] has had to rely on multi-product or multi-firm price indices. Complementing the aggregative studies with micro data-sets focusing on a single firm and single product will, while losing generality, provide additional insights into price-setting behavior. In this paper, we therefore take a detailed look at the characteristics of one such micro dataset, covering a single homogenous product sold in a large number of countries - the cover prices of The Economist magazine.

The dataset spans eleven European countries and the United States over the period 1973-1990; and thus provides a rich setting in which to examine optimal pricing behavior in international markets. Ex ante, a number of characteristics suggest the potential presence of PTM: The Economist is a differentiated product whose price is quoted in the foreign currency and whose time-sensitive nature severely limits international arbitrage possibilities. The dataset has a number of other desirable features as well. First, the product is, by definition, perfectly homogenous. Second, the time-series of prices reflects the pricing decisions of a single producer so that it is possible to study both why and when individual price changes occurred. Moreover, there is no danger of spurious effects arising from compositional, or aggregation, problems. Third, the various destination markets differ along several dimensions, including the average rate of local inflation, and the degree of bilateral exchange rate variability with the production country (the United Kingdom).

In line with a sizeable literature, we are easily able to reject the law of one price, whether in levels or in first-differences, and we estimate exchange rate pass-through coefficients that are significantly lower than unity. On the basis of these standard tests, we would thus conclude that The Economist is priced to market. Yet a more detailed look at the pricing decisions reveals substantially more support for MC-driven than for PTM-driven incomplete passthrough. While we would not like to draw any broad conclusions about international pricing behavior on the basis of a single (perhaps atypical) product, our results do suggest 
that the presence of menu costs, coupled with invoicing in the importers' currency, can lead to spurious findings of pricing to market behavior.

The remainder of the paper is set out in four parts. We first outline the PTM and the menu cost models of pricing behavior. We then present some descriptive statistics for the micro-dataset and present the standard PTM tests, before turning to a more detailed probit analysis to discriminate between PTM and MC determinants of pricing decisions.

\section{Alternative Models of Pricing Behavior}

In this section, we briefly sketch two alternative approaches to pricing behavior in international markets to distinguish between models in which incomplete short run passthrough reflects optimal (and strategic) price-setting behavior and models in which such deviations reflect a failure to adjust nominal prices sufficiently frequently (due, for example, to "menu" costs).

\subsection{Pricing To Market}

Consider a firm that produces both for its domestic market and for export to $n-1$ other countries. The $n$th country is the reference country (in our case, the United Kingdom). In each market the firm may face competition from producers located in its own country; in the foreign market; or a third country. The demand function in country $i$ and at time $t$ is given by $Q_{i t}\left(P_{i t}^{*}\right)$, where $Q_{i t}$ is the firm's exports to that market and $P_{i t}^{*}$ the price expressed in terms of the destination market's currency. Export prices expressed in the reference

currency (in our case, Sterling) will be written $P_{i t}=\frac{P_{i t}^{*}}{E_{i t}}$ where $E_{i t}$ is the exchange rate expressed in units of the foreign currency per unit of the reference currency (so that $E_{n t} \equiv 1$ and an increase in $E$ constitutes an appreciation of the Pound). For notational convenience we also write the reference country price as $P_{n t}^{*}=P_{n t} \equiv P_{t}$.

The firm is assumed to maximize the domestic currency value of its profits:

$$
\operatorname{Max} \Pi=\sum_{t=0}^{T} \delta^{t} \sum_{i=1}^{n} \frac{P_{i t}^{*} Q_{i t}\left(P_{i t}^{*}\right)}{E_{i t}}-C\left(\sum_{i=1}^{n} Q_{i t}\right)
$$

where $T$ is the planning horizon of the firm (which may be infinity), $\delta$ its discount rate (which may be the market interest rate) and $\mathrm{C}()$ denotes the cost function. The first-order conditions imply: 


$$
P_{i t}^{*}=\left[\frac{\eta_{i t}}{\eta_{i t}-1}\right] \frac{D c(Q)}{d Q} E_{i t} \equiv\left(1+\mu_{i t}\right) \frac{d C(Q)}{d Q} E_{i t}
$$

and hence the passthrough elasticity is given by:

$$
\frac{d \log \left(P_{i t}^{*}\right)}{d \log \left(E_{i t}\right)}=1+\frac{d \log \left[\left(1+\mu_{i t}\right) \frac{d C(Q)}{d Q}\right]}{d \log \left(E_{i t}\right)}
$$

where $\eta_{i t}$ is the elasticity of demand in country $i$ and in period $t$, as perceived by the firm, and $\mu$ is defined as the mark-up. The perceived demand elasticity -and hence the passthrough of exchange rate changes- depends upon the market structure in the destination country, opening a wide field of possibilities. If consumers have Dixit-Stiglitz preferences and monopolistic competition prevails, then $\eta_{i t}$ is constant, and depends upon the elasticity of substitution across brands. If the demand function exhibits a constant elasticity of demand, then $\eta_{i t}$ is constant over time but may vary across countries. If demand becomes less elastic as the local currency price rises then the optimal markup decreases as the reference currency appreciates. As Kasa [1993] notes, the generic PTM model (2) thus covers an extraordinary wide range of pricing responses.

The empirical literature typically attempts to overcome this embarrassment of riches by augmenting the null hypothesis with the assumption of a constant elasticity of demand. Dividing (2) by its counterpart for the reference country and taking logarithms gives:

$$
p_{i t}-p_{t}=\log \left(1+\mu_{i t}\right)-\log \left(1+\mu_{n t}\right)
$$

Under the assumption that demand elasticities are time-invariant and using panel data one can then estimate:

$$
p_{i t}=\alpha_{i}+\beta p_{t}+\gamma_{i} e_{i t}+u_{i t}
$$

where the null hypothesis of perfect competition (and thus no pricing to market) is $\alpha_{i}=0, \beta=1, \gamma_{i}=0 \forall i=1, \ldots n-1$. There are two alternative hypotheses. If $\alpha_{i} \neq 0$ then the firm is pricing to market - that is, charging different (Sterling equivalent) prices according to the destination market. If $\alpha_{i} \neq 0$ and $\gamma_{i}<0$, the demand function does not exhibit a constant elasticity and the firm does not pass exchange rate movements fully through to local prices. 
A variant of this level equation underlies most PTM studies; but the equation is also often estimated in first differences (Knetter [1993]):

$$
\Delta p_{i t}=\Delta \alpha_{i}+\beta \Delta p_{t}+\gamma_{i} \Delta e_{i t}+u_{i t}
$$

where the null hypothesis is $\gamma_{i}=0 \forall i=1, \ldots n-1$. The difference version however loses some potentially important information from the levels regression: assuming that exchange rates and nominal prices are non-stationary (which they certainly are in our dataset), equation (4) implies that there is a cointegrating relationship between domestic prices and export prices, unless one is willing to believe that the difference in the optimal mark-ups (arising from differences in the elasticities of demand) is itself a non-stationary variable. Testing the stationarity of the cointegrating residual

$$
\varepsilon_{i t} \equiv p_{i t}-p_{t} \quad i=1, \ldots n-1
$$

thus provides additional information on the PTM model. A failure to reject stationarity admits three explanations. First, the difference in the optimal mark-ups may indeed be a non-stationary variable. Second, the statistical power of the unit root test may be too low. Or third, the underlying model and the regression (5) may be mis-specified, leading to potentially spurious results.

The first possibility cannot be dismissed out-of-hand. For example, with a demand function exhibiting above unitary elasticity the mark-up depends upon the exchange rate (which itself is often a non-stationary variable). Nonetheless, we find intuitively unappealing to think of a potentially unlimited divergence of demand elasticities across markets over time. Likewise, the second possibility likewise cannot be dismissed out of hand, although -for our dataset- seventeen years of monthly data would seem to be a respectable number of observations. To understand how the third possibility might occur it is useful to consider an alternative model of pricing iehavior.

\subsection{Menu Costs}

Assume, as above, that the firm exports to $n-1$ markets but that its profit function is now given by: 


$$
\operatorname{Max} \Pi=\sum_{t=0}^{T} \delta^{t} \sum_{i=1}^{n}\left(1 / E_{i t}\right) P_{i t}^{*}\left(Q_{i t}\right) Q_{i t}-C\left(\sum_{i=1}^{n} Q_{i t}\right)-K\left(\Delta P_{1 t}^{*}, \ldots, \Delta P_{n-1 t}^{*}, \Delta P_{t}\right)
$$

where $K(\bullet)$ is an indicator frunction which captures menu costs of price changes, and where it is assumed that the firm sets the export price in terms of the destination market currency. Menu costs are typically believed to consist of two components: informational and administrative (see Cecchetti [1986]). Informational costs capture the inconvenience imposed on customers - and thus the possible loss of sales - as prices are changed. Administrative costs are associated with determining and implementing new prices (informing distributors, and so forth). For a firm selling in multiple markets, there are likely to be some economies of scale in regard to administrative costs, so that the average cost per price change is declining in the total number of prices changes implemented at a given moment in time.

Menu costs models of this form have been studied by a number of authors [inter alia, Sheshinski and Weiss $(1977,1983)$, Iwai (1981), Benabou (1988)]. These models suggest that even very modest menu costs can lead to an $s S$ pricing rule such that there will be a band of "inactivity" in which prices are not altered even in the presence of rising costs and higher general inflation. Delgado (1991), presenting simulation results for an international extension of the $s S$ model, finds that "with menu costs of the order of $1 \%$ of production costs, the exchange rate can move $50 \%$ and prices will not be changed" [Delgado (1991:480)]. Furthermore, when prices are changed, they are not necessarily set at their unconstrained optimum (i.e. the value which would have been chosen had there been no menu costs) if the direction of future price changes is predictable. For example, with positive trend inflation prices will usually be set above the unconstrained optimum since the firm expects that it will want to raise prices in the future as well. In our context, however, relative prices across markets are likely to be set at their unconstrained optimum (when prices are changed) if the exchange rate follows a random walk without drift. A final important implication of this model class, as stressed by Cecchetti [1986], is "history dependence": changes in the exogenous variables since the previous price change - rather than contemporaneous changes - determine price setting decisions.

Consider, then, any period, $\mathrm{t}$, in which the price in market $i$ is not changed relative to the reference price. Denoting the period of the previous change in price $i$ relative to the 
reference price by 0 , and using equation (4), we can rewrite the cointegrating residual as:

$$
\begin{gathered}
p_{i t}-p_{t}=p_{i t}^{*}-p_{t}-e_{i t}=\left(p_{i t}^{*}-p_{i 0}^{*}\right)-\left(p_{t}-p_{0}\right)-\left(e_{i t}-e_{0}\right)+\left[p_{i 0}^{*}-p_{0}-e_{i 0}\right] \\
=e_{i 0}-e_{i t}+\log \left(1+\mu_{i 0}\right)-\log \left(1+\mu_{n o}\right)
\end{gathered}
$$

The equation illustrates three points. First, if the exchange rate itself is an $I(1)$ process, the cointegrating residual will be non-stationary even when the difference in the optimal markups is $\mathrm{I}(0)$. Second, one would find evidence of local currency price stabilization $\left(\gamma_{i}<0\right)$ even if firms are acting perfectly competitively (i.e. $\left(1+\mu_{i o}\right)=\left(1+\mu_{n o}\right)=1$ ) when they do set prices. Third, when a group of firms pricing according to MC but altering pricing at different times are aggregated to obtain a broader price index, the regression coefficients $\gamma_{i}$ obtained from the aggregate price index may be less than unity (in absolute value).

Non-stationarity of the cointegrating residuals may thus simply reflect the temporary foreign currency price stabilization implied by menu costs. We now turn to our dataset to illustrate that the danger of misinterpretation may be quite relevant in practice.

\section{The Data}

The price dataset consists of the cover prices, in local currency, of The Economist magazine in eleven countries, Austria (AUS), Belgium (BEL), Denmark (DEN), France (FRA), Germany (GER), Italy (ITA), the Netherlands (NET), Norway (NOR), Sweden (SWE), Switzerland (SWI), and the United States (USA), with the United Kingdom serving as the reference country. The sample covers the period from January 1973 to December $1990 .^{2}$ Common currency conversions are based on International Financial Statistics (IFS) exchange rate series converted into local currency per Pound Sterling. Local CPI series were likewise taken from the IFS.

Table 1 provides some basic statistics for our sample. Columns [1], [2], and [3] report the percentage changes in the local currency cover price, the local currency CPI, and the exchange rate, respectively, over the entire sample period. Price changes range from a

\footnotetext{
${ }^{2}$ The sample endpoint reflects a change in the set of prices reported on the cover in January 1991.
} 
Table 1: Descriptive Statistics

\begin{tabular}{||r||r|r|r|r|r|r|r|r|r|r|r||}
\hline \multicolumn{1}{||||}{} & \multicolumn{3}{c|}{ \% Change } & \multicolumn{4}{c||}{$\% \Delta \mathrm{P}_{i}$} & \multicolumn{3}{c||}{ Relative Price } \\
\hline & $\mathrm{P}_{i}$ & $\mathrm{CPI}$ & $\mathrm{E}$ & $\mathrm{Max}$ & $\mathrm{Min}$ & Avg & Std & Max & Min & Avg & Std \\
& {$[1]$} & {$[2]$} & {$[3]$} & {$[4]$} & {$[5]$} & {$[6]$} & {$[7]$} & {$[8]$} & {$[9]$} & {$[10]$} & {$[11]$} \\
& & & & & & & & & & & \\
\hline AUS & 138 & 124 & -62.8 & 19.0 & 2.8 & 6.9 & 4.3 & 170 & 128 & 145 & 18.4 \\
BEL & 271 & 180 & -42.6 & 25.0 & -10.4 & 6.6 & 10.0 & 169 & 124 & 147 & 13.9 \\
DEN & 354 & 292 & -31.6 & 25.0 & -5.8 & 10.1 & 7.6 & 179 & 113 & 150 & 17.9 \\
FRA & 425 & 304 & -18.5 & 25.0 & 5.0 & 11.9 & 7.0 & 177 & 113 & 139 & 17.4 \\
GER & 100 & 86 & -61.8 & 26.6 & 6.3 & 12.4 & 6.5 & 174 & 119 & 143 & 18.5 \\
ITA & 1122 & 730 & 57.2 & 41.6 & 4.1 & 15.2 & 8.4 & 198 & 116 & 154 & 20.2 \\
NET & 190 & 116 & -57.1 & 25.0 & 3.5 & 9.4 & 6.9 & 186 & 115 & 148 & 18.2 \\
NOR & 380 & 301 & -27.5 & 30.0 & -20.0 & 9.6 & 10.6 & 193 & 117 & 144 & 18.3 \\
SWE & 525 & 338 & -3.1 & 58.3 & 4.1 & 13.6 & 13.4 & 223 & 130 & 162 & 24.0 \\
SWI & 107 & 95 & -71.8 & 26.6 & -14.2 & 6.5 & 13.1 & 199 & 127 & 156 & 19.0 \\
USA & 200 & 213 & -18.2 & 25.0 & 11.1 & 17.0 & 4.5 & 189 & 136 & 165 & 18.4 \\
UK & 540 & 472 & NA & 25.0 & 6.6 & 13.2 & 5.3 & NA & NA & NA & NA \\
\hline
\end{tabular}

doubling in Germany to a more than eleven-fold increase in Italy, with the UK towards the upper end. With the sole exception of the United States, the price change of The Economist has exceeded the change in the overall consumer price index. The local price change, relative to the UK price change, broadly tracks the exchange rate movement over the sample: low (Economist price) inflation Austria, Germany, and Switzerland logged appreciations between 60 and $70 \%$ while high inflation Italy depreciated by almost $60 \%$ vis a vis Sterling.

Columns [4] to [7] report the maximum, minimum and average percentage change of the local currency price and its standard deviation. Price changes display substantial variation, ranging from $-20 \%$ to $+58 \%$, with the standard deviation in several cases exceeding the mean. A histogram reveals the majority of price changes to be in the 3 to $12 \%$ range. Columns [8] to [11] report the maximum, minimum, average, and standard deviation of the ratio of the (Sterling equivalent) of the foreign price to the Sterling price (that is, the common currency relative price) in those months in which the foreign currency price was changed. Again the data reveal substantial variability and do not immediately suggest obvious trigger points. On average, price adjustments seem to be undertaken once the relative price has strayed by between 40 and $60 \%$ from unity, with substantial differences 
both within, and across, countries.

Table 2: Mean and Standard Deviation Of Bilateral Relative Price

\begin{tabular}{|c|c|c|c|c|c|c|c|c|c|c|c|}
\hline & AUS & BEL & DEN & FRA & GER & ITA & NET & NOR & SWE & SWI & UK \\
\hline $\begin{array}{l}\text { BEL } \\
\text { DEN } \\
\text { FRA } \\
\text { GER } \\
\text { ITA } \\
\text { NET } \\
\text { NOR } \\
\text { SWE } \\
\text { SWI } \\
\text { UK } \\
\text { USA }\end{array}$ & $\begin{array}{l}0.89 \\
0.08 \\
0.94 \\
0.08 \\
0.90 \\
0.06 \\
0.99 \\
0.06 \\
0.98 \\
0.14 \\
0.96 \\
0.06 \\
0.92 \\
0.12 \\
1.02 \\
0.13 \\
1.02 \\
0.09 \\
0.64 \\
0.10 \\
1.03 \\
0.20\end{array}$ & $\begin{array}{l}1.05 \\
0.07 \\
1.01 \\
0.07 \\
1.13 \\
0.17 \\
1.09 \\
0.14 \\
1.08 \\
0.11 \\
1.03 \\
0.11 \\
1.15 \\
0.12 \\
1.15 \\
0.15 \\
0.72 \\
0.07 \\
1.16 \\
0.21\end{array}$ & $\begin{array}{l}0.96 \\
0.06 \\
1.07 \\
0.13 \\
1.04 \\
0.13 \\
1.02 \\
0.06 \\
0.98 \\
0.09 \\
1.09 \\
0.09 \\
1.09 \\
0.10 \\
0.68 \\
0.09 \\
1.10 \\
0.21\end{array}$ & $\begin{array}{l}1.11 \\
0.12 \\
1.08 \\
0.14 \\
1.07 \\
0.07 \\
1.03 \\
0.12 \\
1.14 \\
0.11 \\
1.14 \\
0.11 \\
0.71 \\
0.10 \\
1.15 \\
0.22\end{array}$ & $\begin{array}{l}0.98 \\
0.18 \\
0.96 \\
0.08 \\
0.93 \\
0.16 \\
1.03 \\
0.16 \\
1.02 \\
0.10 \\
0.65 \\
0.12 \\
1.04 \\
0.22\end{array}$ & $\begin{array}{l}1.00 \\
0.14 \\
0.96 \\
0.14 \\
1.06 \\
0.13 \\
1.07 \\
0.16 \\
0.67 \\
0.10 \\
1.08 \\
0.24\end{array}$ & $\begin{array}{l}0.96 \\
0.10 \\
1.07 \\
0.10 \\
1.07 \\
0.07 \\
0.67 \\
0.09 \\
1.08 \\
0.20\end{array}$ & $\begin{array}{l}1.12 \\
0.11 \\
1.12 \\
0.14 \\
0.70 \\
0.08 \\
1.13 \\
0.19\end{array}$ & $\begin{array}{l}1.00 \\
0.12 \\
1.00 \\
0.12 \\
1.01 \\
0.18\end{array}$ & $\begin{array}{l}0.63 \\
0.10 \\
1.01 \\
0.19\end{array}$ & $\begin{array}{l}1.01 \\
0.19\end{array}$ \\
\hline $\begin{array}{l}\text { Avg. S.E. } \\
\text { Avg. Mean }\end{array}$ & $\begin{array}{l}0.10 \\
0.94\end{array}$ & $\begin{array}{l}0.12 \\
1.06\end{array}$ & $\begin{array}{l}0.11 \\
1.00\end{array}$ & $\begin{array}{l}0.12 \\
1.05\end{array}$ & $\begin{array}{l}0.15 \\
0.94\end{array}$ & $\begin{array}{l}0.15 \\
0.97\end{array}$ & $\begin{array}{l}0.11 \\
0.97\end{array}$ & $\begin{array}{l}0.13 \\
1.02\end{array}$ & $\begin{array}{l}0.14 \\
1.00\end{array}$ & $\begin{array}{l}0.15 \\
0.82\end{array}$ & $\begin{array}{l}0.19 \\
1.01\end{array}$ \\
\hline
\end{tabular}

First row: mean. Second row: standard deviation.

AUS: Austria, BEL: Belgium, DEN: Denmark, FRA: France, GER: Germany, ITA: Italy, NET:

Netherlands, NOR: Norway, SWE: Sweden, SWI: Switzerland, UK: United Kingdom

Table 2 reports the mean relative price (and its standard deviation) across different markets. With the exception of the UK prices (which are almost uniformly lower than the price in any other country), the maximum deviation of the relative price from unity is in the order of fifteen percent (which is roughly the same magnitude of the standard deviation). The table serves primarily to remind us that, given the time-sensitive nature of the product, these markets are generally segmented with international arbitrage possibilities severely limited. For example, the relative price in Austria and Germany is very close to unity (suggesting, perhaps, some local arbitrage possibilities) but the relative price between France and the United States is the same as the relative price between France and Switzerland, even though local arbitrage in the latter case must be much less costly. The volatility of these relative prices, relative to their mean, is also revealing: they are significantly higher fo- the United States and the United Kingdom - countries whose cur- 
rencies floated against those of the other countries over much of the sample period. With this simple characterization of the basic data in mind, we turn next to some formal tests of pricing behavior.

\section{Pricing To Markets}

The evidence presented in tables 1 and 2 suggests strongly that the law of one price does not hold continuously for The Economist. The purpose of this section is to determine using the methodology adopted by previous studies - whether The Economist is "pricedto-market". We use two tests. The first examines whether the Sterling equivalent price in different destination markets is affected by the Sterling exchange rate. Under the null hypothesis of perfectly competitive behavior there should be no effect. The second test is an "exchange rate pass-through" regression in which the local currency price is regressed on the Sterling exchange rate. If exchange rate movements are not being offset then there should be a unit coefficient on the exchange rate.

\subsection{Import-Currency Price Stabilization Regressions}

In order to test whether firms stabilize local currency prices we estimate both single timeseries and panel versions of equations (5) and (6). In the absence of transportation costs, constants significantly different from zero (or the coefficients, $\alpha_{i}$, in the panel regressions) could be interpreted as evidence in favor of PTM. Since we observe local currency retail prices which are not independent of transportation costs, however, the interpretation of the constants is less clearcut, a shortcoming this study shares with the literature at large. ${ }^{3}$

The main focus thus falls on the exchange rate coefficients $\gamma_{i}$. Significantly negative coefficients are generally interpreted as evidence in favor of PTM. In an extreme case, a coefficient of -1 would indicate that none of the Sterling appreciation had been allowed to pass-through to import currency prices. Table 3 reports the results for the levels and the first difference regression. (The row marked "panel" is a panel regression with coefficients constrained to be equal across countries). The results are quite strong: the coefficient on the exchange rate is always negative (at very high statistical levels of significance) and is often close to -1.0 . Within the PTM framework, this finding would be interpreted as

\footnotetext{
${ }^{3}$ An exception is Knetter (1993).
} 
Table 3: Pricing To Markets - Levels And Growth Rates

\begin{tabular}{|c|c|c|c|c|c|c|c|c|}
\hline \multirow[b]{2}{*}{ Country } & \multicolumn{5}{|c|}{ Levels } & \multicolumn{3}{|c|}{ Growth Rates } \\
\hline & Const. & Trend & UK P. & Exch. & $\mathrm{R}^{2}$ & $\Delta($ UK P.) & $\Delta$ (Exch.) & $\mathrm{R}^{2}$ \\
\hline AUS & $\begin{array}{l}2.70^{* *} \\
(35.70)\end{array}$ & $\begin{array}{l}0.004^{* *} \\
(17.66)\end{array}$ & $\begin{array}{l}0.10^{* *} \\
(4.77)\end{array}$ & $\begin{array}{l}-0.88^{* *} \\
(-42.63)\end{array}$ & 0.99 & $\begin{array}{l}0.24^{* *} \\
(2.63)\end{array}$ & $\begin{array}{l}-0.90^{* *} \\
(-13.91)\end{array}$ & 0.65 \\
\hline BEL & $\begin{array}{l}2.03^{* *} \\
(14.46)\end{array}$ & $\begin{array}{l}0.001 \\
(2.41)^{* *}\end{array}$ & $\begin{array}{l}0.76^{* *} \\
(18.51)\end{array}$ & $\begin{array}{l}-0.44^{* *} \\
(-13.44)\end{array}$ & 0.99 & $\begin{array}{l}0.58^{* *} \\
(3.45)\end{array}$ & $\begin{array}{l}-1.05^{* *} \\
(-11.53)\end{array}$ & 0.52 \\
\hline DEN & $\begin{array}{l}2.00^{* *} \\
(20.01)\end{array}$ & $\begin{array}{l}0.00 \\
(0.76)\end{array}$ & $\begin{array}{l}0.84^{* *} \\
(19.54)\end{array}$ & $\begin{array}{l}-0.67^{* *} \\
(-17.11)\end{array}$ & 0.98 & $\begin{array}{l}0.49^{* *} \\
(3.18)\end{array}$ & $\begin{array}{l}-0.89^{* *} \\
(-11.73)\end{array}$ & 0.50 \\
\hline FRA & $\begin{array}{l}2.50^{* *} \\
(44.88)\end{array}$ & $\begin{array}{l}0.001^{* *} \\
(4.75)\end{array}$ & $\begin{array}{l}0.88^{* *} \\
(32.25)\end{array}$ & $\begin{array}{l}-1.00^{* *} \\
(-39.41)\end{array}$ & 0.99 & $\begin{array}{l}0.49^{* *} \\
(3.13)\end{array}$ & $\begin{array}{l}-1.12^{* *} \\
(-8.41)\end{array}$ & 0.57 \\
\hline GER & $\begin{array}{l}1.59^{* * *} \\
(22.11)\end{array}$ & $\begin{array}{l}0.001^{* *} \\
(3.88)\end{array}$ & $\begin{array}{l}0.22^{* *} \\
(7.61)\end{array}$ & $\begin{array}{l}-1.11^{* *} \\
(-34.95)\end{array}$ & 0.99 & $\begin{array}{l}0.20 \\
(1.54)\end{array}$ & $\begin{array}{l}-0.99^{* *} \\
(-13.64)\end{array}$ & 0.59 \\
\hline ITA & $\begin{array}{l}6.97^{* *} \\
(10.67)\end{array}$ & $\begin{array}{l}0.002^{* *} \\
(3.92)\end{array}$ & $\begin{array}{l}1.06^{* *} \\
(13.14)\end{array}$ & $\begin{array}{l}-0.90^{* *} \\
(-11.37)\end{array}$ & 0.98 & $\begin{array}{l}0.61^{* *} \\
(2.94)\end{array}$ & $\begin{array}{l}-1.05^{* *} \\
(-7.53)\end{array}$ & 0.40 \\
\hline NET & $\begin{array}{l}1.87^{* *} \\
(26.65)\end{array}$ & $\begin{array}{l}-0.001 * * \\
(-3.92)\end{array}$ & $\begin{array}{l}0.68^{* *} \\
(22.00)\end{array}$ & $\begin{array}{l}-0.99^{* *} \\
(-26.61)\end{array}$ & 0.99 & $\begin{array}{l}0.35^{* *} \\
(2.61)\end{array}$ & $\begin{array}{l}-0.96^{* *} \\
(-16.76)\end{array}$ & 0.55 \\
\hline NOR & $\begin{array}{l}2.35^{* * *} \\
(14.81)\end{array}$ & $\begin{array}{l}0.00 \\
(0.50)\end{array}$ & $\begin{array}{l}0.91^{* *} \\
(16.17)\end{array}$ & $\begin{array}{l}-0.85^{* *} \\
(-14.08)\end{array}$ & 0.97 & $\begin{array}{l}0.42^{* *} \\
(2.19)\end{array}$ & $\begin{array}{l}-0.76^{* *} \\
(-5.61)\end{array}$ & 0.25 \\
\hline SWE & $\begin{array}{l}2.37^{* *} \\
(16.35)\end{array}$ & $\begin{array}{l}0.00 \\
(-1.50)\end{array}$ & $\begin{array}{l}0.97^{* *} \\
(21.51)\end{array}$ & $\begin{array}{l}-0.86^{* *} \\
(-15.77)\end{array}$ & 0.97 & $\begin{array}{l}0.66^{* *} \\
(2.07)\end{array}$ & $\begin{array}{l}-1.07^{* *} \\
(-8.44)\end{array}$ & 0.46 \\
\hline SWI & $\begin{array}{l}1.13^{* *} \\
(12.05)\end{array}$ & $\begin{array}{l}0.003^{* *} \\
(4.17)\end{array}$ & $\begin{array}{l}0.12 \\
(1.81)\end{array}$ & $\begin{array}{l}-0.93^{* *} \\
(-19.33)\end{array}$ & 0.98 & $\begin{array}{l}0.29 \\
(1.42)\end{array}$ & $\begin{array}{l}-0.96^{* *} \\
(-11.19)\end{array}$ & 0.38 \\
\hline USA & $\begin{array}{l}1.37^{* *} \\
(25.31)\end{array}$ & $\begin{array}{l}-0.004^{* *} \\
(-4.46)\end{array}$ & $\begin{array}{l}1.00^{* *} \\
(22.25)\end{array}$ & $\begin{array}{l}-0.88^{* *} \\
(-31.34)\end{array}$ & 0.98 & $\begin{array}{l}0.37^{* *} \\
(2.88)\end{array}$ & $\begin{array}{l}-0.98^{* *} \\
(-20.58)\end{array}$ & 0.56 \\
\hline PANEL & $\begin{array}{l}-0.01 \\
(-0.33)\end{array}$ & $\begin{array}{l}0.003^{* *} \\
(10.59)\end{array}$ & $\begin{array}{l}0.58^{* *} \\
(18.40)\end{array}$ & $\begin{array}{l}-0.01^{* *} \\
(-5.38)\end{array}$ & 0.93 & $\begin{array}{l}0.43^{* *} \\
(7.36)\end{array}$ & $\begin{array}{l}-0.97^{* *} \\
(-33.77)\end{array}$ & 0.46 \\
\hline
\end{tabular}


evidence that producer altered home currency prices to stabilize foreign currency prices in the face of exchange rate movements.

\subsection{Exchange Rate Pass-Through Tests}

We next turn to standard passthrough regressions. In these tests, the change in the local currency price, $\Delta p_{i t}^{*}$ is regressed on the change in the reference price, $\Delta p_{t}$, and the current and lagged values of the change in the exchange rate:

$$
\Delta p_{i t}^{*}=\beta \Delta p_{t}+\sum_{j=0}^{k} \gamma_{i k} \Delta e_{i t-j}+\varepsilon_{i t}
$$

The passthrough elasticity at lag $\mathrm{k}$ is then given by $\gamma(k)=\sum_{j=0}^{k} \gamma_{i k}$ and immediate complete pass-through (i.e. no local currency price stabilization) implies $\gamma(0)=1$. Table 4 reports the $\gamma(12)$ coefficients - allowing for some sluggish adjustment - for the entire sample period and separately for the $1973-79$ and $1980-90$ period. For the entire sample period the estimated pass-through coefficient is well below unity in every case. The pass-through coefficients rise in the second sub-sample in each case (with the exception of Belgium) reflecting, perhaps, lower volatility of nominal exchange rates with the development of the EMS.

Table 4: Exchange Rate Pass-Through (12 Months)

\begin{tabular}{||c||c|c|c|c|c|c|c|c|c|c|c||}
\hline & AUS & BEL & DEN & FRA & GER & ITA & NET & NOR & SWE & SWI & USA \\
\hline $1973-90$ & 0.24 & 0.63 & 0.39 & 0.03 & 0.13 & -0.09 & 0.13 & 0.32 & 0.37 & 0.25 & 0.15 \\
$1973-79$ & -0.15 & 0.84 & 0.03 & -0.44 & -0.45 & -1.42 & -0.39 & 0.30 & -0.06 & 0.16 & 0.08 \\
$1980-90$ & 0.43 & 0.72 & 0.60 & 0.30 & 0.34 & 0.24 & 0.33 & 1.09 & 0.65 & 0.25 & 0.13 \\
\hline
\end{tabular}

Both the PTM and the passthrough equations thus strongly indicate that nominal exchange rate movements were not fully reflected in the export price.

We noted above that if (Sterling equivalent) export prices are being adjusted to offset nominal exchange rate movements in each period - one interpretation of the above results - then these prices should reflect the optimal mark-up. Excluding the (rather unlikely) 
possibility that the difference in the optimal markup across markets is non-stationary, it follows that the equivalent currency price ratio should follow a stationary stochastic process. Table 5 reports the twelve lag augmented Dickey Fuller statistics both for an "unrestricted" test [Column 1] on the residual obtained from a regression of the Sterling equivalent foreign price, $p_{i t}$, on the Sterling price, $p_{t}$, and for a "restricted" test [Column 2] in which a unit coefficient on the Sterling price is imposed when calculating the cointegrating residual. Column 3 reports the ADF statistic for the first difference specification.

Table 5: Co-Integration Tests (ADF)

\begin{tabular}{||l||l|l|l||}
\hline & {$[1]$} & {$[2]$} & {$[3]$} \\
\hline AUS & $-3.20^{* *}$ & -0.06 & $-4.49^{* *}$ \\
BEL & $-4.00^{* *}$ & -3.02 & $-4.01^{* *}$ \\
DEN & -2.88 & -2.55 & $-3.25^{* *}$ \\
FRA & $-3.34^{* *}$ & $-4.65^{* *}$ & $-4.83^{* * *}$ \\
GER & -3.04 & 1.09 & $-4.29^{* * *}$ \\
ITA & -1.75 & -1.89 & $-5.47^{* * *}$ \\
NET & -3.02 & -1.84 & $-5.33^{* * *}$ \\
NOR & -2.16 & -1.34 & $-4.21^{* *}$ \\
SWE & -2.73 & -3.05 & $-4.57^{* *}$ \\
SWI & $-3.75^{* *}$ & -0.55 & $-3.86^{* *}$ \\
USA & -2.42 & -1.27 & $-6.21^{* *}$ \\
\hline
\end{tabular}

A rejection of the unit root - as implied by (4) - is only possible for four cases in the unrestricted and only one case in the restricted version, casting doubt on the appropriateness of the PTM model.

\section{Menu Costs}

Regression tests of the form used above are not useful for distinguishing whether incomplete passthrough arises from sluggish price adjustment in the presence of menu costs or reflects deliberate attempts to offset nominal exchange rate movements. In order to distinguish between these two possibilities we now turn to Probit analysis of the determinants of foreign price increases. Specifically, we examine two testable hypothesis:

- History Dependence. In the MC model, the cumulative exchange rate movement since the last price change will determine current pricing decisions. In the PTM 
model, only the current exchange rate movement matters.

Let $\tau$ denote the time period of the previous increase in the foreign price then, for any variable $x_{t}$, we define $\tilde{x}_{t}=\left(x_{t}-x_{\tau}\right) / x_{\tau} ;$ that is, the percentage deviation in $x$ since the previous price change. Let $z_{i t}=\left(e_{i t}+p_{t}\right)-p_{i t}^{*}$ denote the deviation from the law of one price. Since there are transportation costs, the law of one price will not hold exactly. However, if pricing decisions reflect menu costs rather than PTM decisions, then what should matter for predicting the next price increase is the deviation from the law of one price since the previous change. Thus we expect $\tilde{z}_{i t}$, rather than $z_{i t}$ or $\Delta z_{i t}$, to help predict price increases.

- Bunching Of Price Changes. In the PTM model, the decision to change a price in country $i$ is independent of whether prices in other countries are changed at the same time. In the $\mathrm{MC}$ model, decreasing average menu costs suggest bunching of price changes in a given period. The number of price changes in other markets (OTHER) should thus enter positiveiy in the Probit regression if menu costs are present, but should be insignificant if PTM considerations are relevant.

In addition to the above mentioned variables, we include the local inflation rate, $\Delta p_{i t}^{* c}$, and the change in the consumer price inflation since the last price change, $\tilde{p}_{i t}^{* c}$ as proxies for PTM effects. Finally, we use the wholesale price inflation in the United Kingdom to capture increases in production costs. ${ }^{4}$.

The results of the probit estimation are reported in table 5. For both hypothesis, the evidence is strongly in favor of menu costs. Eqn [1] shows that the deviation since the last price change is significant and of the correct sign, while the deviation itself enters insignificantly. Similarly, it is the deviation of the exchange rate since the last price change, rather than the change in the exchange rate itself which enters. The regressions thus point strongly to the presence of history dependence. The second hypothesis is likewise supported: the number of other price changes (OTHER) enter significantly and positively

\footnotetext{
The Sterling price of The Economist is an alternative candidate, but will -under the null-itself suffer from menu costs induced "stickiness". The overall price index, by averaging over a wide array of prices adjusted at different times, is likely to be a better approximation. As a crude proxy, we also tried a linear time-trend to capture changes in costs (following Knetter [1989]), the coefficient estimates and standard errors for the other variable were almost identical.
} 
Table 6: Probit Estimation of Price Changes

\begin{tabular}{|c|c|c|c|c|c|c|c|c|c|c|}
\hline & Const. & $\Delta p_{t}^{w}$ & $\Delta p_{i t}^{c *}$ & $\tilde{p}_{i t}^{* c}$ & $\tilde{e}_{i t}$ & $\bar{z}_{i t}$ & OTHER & $\Delta e_{i t}$ & $z_{i t}$ & $R^{2}$ \\
\hline Eqn.[1] & $i$ & $\begin{array}{l}122.50^{* *} \\
(3.10)\end{array}$ & $8 * *$ & 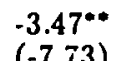 & & & 0 & & & 0.88 \\
\hline Eqn.[2] & $\begin{array}{l}(-4.50) \\
-2.22^{*}\end{array}$ & $\begin{array}{l}(3.10) \\
106.62^{* *}\end{array}$ & $\begin{array}{l}(6.05) \\
219.48^{* *}\end{array}$ & $\begin{array}{l}(-7.73) \\
-3.24^{* *}\end{array}$ & $0.17^{* *}$ & & $\begin{array}{l}(8.65) \\
0.43^{*}\end{array}$ & & & 0 \\
\hline & $(-8.91)$ & $(3.08)$ & $(6.11)$ & $(-8.37)$ & (5.36) & & $(8.78)$ & & & \\
\hline Eqn.[3] & $-2.26^{\circ}$ & $114.50^{\circ * *}$ & $232.77^{*}$ & $-3.47^{\circ}$ & & $0.06^{* \circ}$ & $0.41^{*-2}$ & & & 0.88 \\
\hline Eqn. & $(-8.93)$ & $\begin{array}{l}(3.17) \\
112\end{array}$ & $(6.06)$ & $(-7.72)$ & & $(4.81)$ & $(6.06)$ & & & \\
\hline Eqn.l & $\begin{array}{l}-2.31^{* *} \\
(-8.76)\end{array}$ & $\begin{array}{l}112.27^{\circ *} \\
(3.17)\end{array}$ & $\begin{array}{l}230.87^{* *} \\
(6.06)\end{array}$ & $\begin{array}{l}-3.34^{* *} \\
(-7.72)\end{array}$ & $\begin{array}{l}0.18 \\
(5.61)\end{array}$ & & $\begin{array}{l}0.43^{\circ *} \\
(8.78)\end{array}$ & $\begin{array}{l}-10.60 \\
(-1.07)\end{array}$ & & 0.88 \\
\hline Eqn.[5] & $\begin{array}{l}-2.311^{* 8} \\
(-8.48)\end{array}$ & $\begin{array}{l}126.21^{* *} \\
(3.25)\end{array}$ & $\begin{array}{l}243.59^{* *} \\
(5.95)\end{array}$ & $\begin{array}{l}-3.92^{-1} \\
(-7.47)\end{array}$ & $\begin{array}{l}0.14^{* 6} \\
(3.48)\end{array}$ & $\begin{array}{l}0.04^{*-} \\
(2.95)\end{array}$ & $\begin{array}{l}0.43^{*} \\
(8.44)\end{array}$ & & & 0.89 \\
\hline
\end{tabular}

in all regressions.

Turning to the other variables, an increase in the UK wholesale price inflation, $\Delta p_{t}^{w}$, or the consumer price inflation in the destination market, $\Delta p_{i t}^{c *}$, raises the probability of a price increase. An increase in the consumer price index since the last price increase, $\tilde{p}_{i t}^{* c}$, controlling for the other variables, decreases the probability of a price increase. This result is counter-intuitive, but is similar to the findings of Cechetti [1986] in his study of magazine pricing in the US market.

If sluggish price adjustments indeed reflects menu costs, and if firms did price competitively when they did adjust prices, we would expect complete passthrough if we only look at those months in which prices are actually adjusted. Table 5 reports the results obtained by a panel regression of the change in the relative price in currency $i$ to the Sterling price between two months in which the foreign price was adjusted on the change in the exchange rate between those two periods. To allow for some administrative lags between exchange rate movements and subsequent price, we also report results using the depreciation rate six months before the price change.

The exchange rate change between two price adjustments is seen to play a highly significant role in determining relative price adjustment. For the contemporaneous change, the unit coefficient cannot be rejected at the $10 \%$ level, for the six month leaded series, it cannot be rejected at the five percent level. There is thus substantial evidence that -once 
Table 7: The Law Of One Price- Revisited

\begin{tabular}{||l|c|c||}
\hline & Constant & $\begin{array}{c}\text { Depreciation } \\
\text { Rate }\end{array}$ \\
\hline Simultaneous & $\begin{array}{c}0.33^{* *} \\
(2.30)\end{array}$ & $\begin{array}{c}0.672^{* *} \\
(4.62)\end{array}$ \\
\hline Six months lag & $\begin{array}{c}0.15 \\
(1.04)\end{array}$ & $\begin{array}{c}0.85 \mathrm{q}^{* *} \\
(5.63)\end{array}$ \\
\hline
\end{tabular}

t-statistics in brackets.

prices are adjusted-passthrough is complete. Comparing the results of table 5 with table 4 it is clear that low average passthrough resulting from looking at a sample combining "zero passthrough" observations in most months with "complete" passthrough observations in those months in which prices are changed may easily, but incorrectly, be interpreted as evidence of pricing to market.

\section{Conclusions}

In this paper we have tried to distinguish between deliberate attempts at offsetting nominal exchange rate movements, and inadvertent import-currency price stabilization stemming from menu costs. The distinction is important because, inter alia, it determines the speed of adjustment of the real exchange rate to nominal exchange rate movements (with the presumption being that deliberate pricing to market will cause longer lags in such adjustment). Moreover, deliberate pricing to market is inconsistent with competitive behavior and, arguably, borders on an unfair trade practice. Inadvertent price stabilization, in contrast, is quite consistent with price-taking firms that cannot change prices frequently without incurring menu costs. We have also argued that standard tests can lead to spurious findings of pricing to market when menu costs are present. The shortcomings of these tests may be masked, moreover, due to aggregation problems when the price series are composite indices. Using a panel dataset of prices in eleven countries for a single firm, we find that standard pricing to market and exchange rate pass-through tests may yield spurious results. 


\section{References}

[1] Baldwin, Richard E. (1988); "Hysteresis in Import Prices: the Beach head Effect"; American Economic Review, September, 773-85.

[2] Benabou, Roland (1988); "Search, Price Setting, and Inflation"; Review of Economic Studies; pp. 353-376.

[3] Cecchetti, Stephen G. (1986), "The Frequency of Price Adjustment: A Study of Newsstand Prices of Magazines"; Journal of Econometrics; pp. 255-274.

[4] Delgado, Francisco (1991); "Hysteresis, menu costs, and pricing with random exchange rates"; Journal of Monetary Economics; 28, 461-84.

[5] Dixit, Avinash (1989); "Hysteresis, Import Penetration and Exchange Rate Passthrough"; Quarterly Journal of Economics; May, 205-28.

[6] Dornbusch, Rüdiger (1987); "Exchange Rates and Prices"; American Economic Review; March, 93-106.

[7] Feenstra, Robert, Joseph Gagnon and Michael Knetter (1993); "Market Share and Exchange Rate Pass-Through in World-Automobile Trade"; NBER Working Paper No. 4399 , July.

[8] Froot, Kenneth and Paul Klemperer (1989); "Exchange Rate Pass-Through When Market Share Matters"; American Economic Review, September, 79:637-654.

[9] Harrison, Ann (1993); "Imperfect Explanations for Imperfect Pass-Through: Market Power and Exchange Rates in the U.S. Steel Industry"; mimeo.

[10] Hooper, Peter and Catherine L. Mann (1989); "Exchange Rate Pass-Through in the 1980's: The Case of U.S. Manufactures"; Brookings Papers on Economic Activity. 1:1989.

[11] Iwai, K. (1982); Disequilibrium Dynamics; Yale University Press: New Haven.

[12] Kasa, Kenneth (1992); "Adjustment Costs and Pricing-to-Market: Theory and Evidence"; Journal of International Economics; February, 1-27. 
[13] Knetter, Michael (1989); "Price Discrimination by U.S. and German Exporters"; American Economic Review , 79:198-209.

[14] Knetter, Michael (1993); "International Comparisons of pricing-to-Market Behavior"; American Economic Review, 83: 473-486.

[15] Krugman, Paul (1986); "Pricing to Market When the Exchange Rate Changes"; NBER Working Paper No. 1926, May.

[16] Melick, William R. (1990); "Estimating Pass-Through: Structure and Stability"; Federal Reserve Board of Governors Discussion Paper No. 387.

[17] Sheshinski, Eytan and Yoram Weiss (1977), "Inflation and Costs of Price Adjustment," Review of Economic Studies, 44, pp. 281-303.

[18] Sheshinski, Eytan and Yoram Weiss (1983), "Optimal Pricing Policy Under Stochastic Inflation," Review of Economic Studies, 51, pp. 513-529. 